\title{
Ecological Determinants of Spionid Distributions Within Dense Patches of Deposit-Feeding Polychaete Axiothella rubrocincta
}

\author{
J. R. Weinberg* \\ The University of the Pacific, Pacific Marine Station, Dillon Beach, California 94929, USA
}

\begin{abstract}
Total spionid polychaete density (composed of eight species) on a California sandflat was significantly lower within dense, upper-intertidal patches of the tube-dwelling polychaete Axiothella rubrocincta (Maldanidae). Interspecific competition for a limited supply of organic-mineral aggregates (OMA) between A. rubrocincta and the spionid guild was implicated to account for the spionid distribution pattern at these patches. 'Within Patch' sediments contained significantly less OMA than sediments on the 'Outer Edges' of patches, at equivalent tidal heights ( $2 \%$ vs. $25 \%$ ). By contrast, at a lower intertidal $A$. rubrocincta patch, where OMA abundance $(42 \%)$ was significantly greater, spionids were equally dense inside and outside. OMA were found to be an important selected food of deposit-feeding adult A. rubrocincta and Pseudopolydora paucibranchiata (Spionidae). In addition, OMA are incorporated into the spionid tubes (found in all six species checked). The sediment reworking, feeding activity of $A$. rubrocincta depletes OMA abundance in the sediment, both in the laboratory and in nature. OMA depletion was experimentally shown to lower adult $P$. paucibranchiata feeding and tube-building rates because of a strong OMA 'preference'. Furthermore, adult $P$. paucibranchiata had higher mortality and lower larval recruitment when in sympatry with A. rubrocincta. Pseudopolydora kempi (Spionidae) larval recruitment was significantly lower in cultures containing A. rubrocincta. Predatory flatfish were attracted by and attacked feeding $P$. paucibranchiata. These attacks were unsuccessful when the spionid food (OMA) supply was abundant as spionids were able to withdraw rapidly into their tubes. When food abundance was low, a condition found within upper-intertidal A. rubrocincta patches, spionids extended farther out of their tubes to increase their OMA search area. This behavior is likely to increase the probability of a successful attack by a predatory fish.
\end{abstract}

\section{INTRODUCTION}

Interspecific interactions have been shown to play critical roles in determining distributional patterns of species in marine rocky intertidal (i.e. Connell, 1961; Paine, 1966; Dayton, 1971) and terrestrial (i.e. Harper, 1969; Pianka, 1973; Cody, 1974) communities. Though less clearly demonstrated, the importance of interspecific interactions has recently been indicated in marine, soft-substrate communities (i.e. Woodin, 1974; Fenchel et al., 1975; Ronan, 1975; Whitlatch, 1976; Levinton, 1977; Reise, 1978). Because soft-substrates are readily characterized by their physical properties, much of the early ecological research on this habitat focused upon correlating species of infauna with sediment types. However, soft-substrates are equally amenable to studies on the importance of biological interactions in community structure, as they often support diverse communities within a structurally simple

\footnotetext{
- Present address: The University of Connecticut, Marine
} Research Laboratory, Noank, Ct. 06340, USA. habitat. Furthermore, dense invertebrate patches, dominated by a single infaunal species, are a common feature of soft-substrate communities (for examples see Woodin, 1976).

Unique distributional patterns of other nearby species could be determined by competitive and/or predatory interactions with the patch-forming species. In addition, environmental differences among habitats (i.e. intertidal patches located at different tidal heights) could alter the nature of these biological interactions, producing alternate distributions. The purpose of this study was to investigate the roles of interspecific interactions (adult-adult and adult-larval) in determining the spionid polychaete guild distributional pattern around dense maldanid polychaete patches which were located in habitats with environmental differences. A 'guild' is defined as a group of species that exploit the same class of environmental resources in a similar way relative to other species (Root, 1967). At the community level, the guild concept can be very useful because many species can be lumped into a single exploitation group. Woodin 
(1976) and Fauchauld and Jumars (in press) have recently applied this concept to the soft-substrate habitat.

The interactions investigated in this study included interspecific competition for limited resources, differential predation on spionids within Axiothella rubrocincta patches, and physical unsuitability of $A$. rubrocincta patches for spionids. These mechanisms are not considered to be mutually exclusive. Data were obtained on: (1) A. rubrocincta-spionid densities and distribution; (2) A. rubrocincta resource utilization and substrate modification; (3) spionid resource utilization and interactions with $A$. rubrocincta; and (4) the spionid predator escape response.

\section{THE STUDY AREA}

This study was conducted on a south-facing intertidal sandflat, known locally as Lawson's Flat, in Tomales Bay, California, U.S.A. (38 $13^{\circ} \mathrm{N}$ and $122^{\circ} 58^{\prime} \mathrm{W}$, Fig. 1). Tides in this region are of mixed semidiumal nature and salinities vary from 30-35\% throughout most of the year (Johnson, 1971). The large sandflat, characterized by well-sorted, medium-grained sands has an average slope of about $1^{\circ}$ (see Johnson, 1965, $1967 \mathrm{a}, \mathrm{b}, 1970$, and Deatwyler, 1966, for a more complete description of the area). The surficial sediments on Lawson's Flat contain large quantities of organicmineral aggregates (OMA). This particulate material consists of an amorphous organic matrix surrounding clay and silt-sized mineral particles $(<88 \mu \mathrm{m}$ ) (see Zabawa, 1978, for a description of the physical properties of OMA). OMA are considered to be an important food resource to deposit feeders due to their high organic content (Johnson, 1974) and bacterial, meiofaunal, and microfloral associates (Hargrave, 1972; Taghon et al., 1978). OMA are major constituents of surficial sediments from the intertidal zone to depths of $5000 \mathrm{~m}$ (Johnson, 1977).

Areas of Lawson's Flat inhabited by Axiothella rubrocincta, exhibit a distinctive (funnel and volcanolike) surficial topography, which is caused by this polychaete's deposit-feeding activity. A. rubrocincta inhabits a U-shaped sandy tube, with surface openings for feeding and defecation (Kudenov, 1971; personal observation) '. Individuals form large, dense patches. Three patches were chosen as study areas in June, 1975. Patch \#2 was approximately 500 m northeast of the other patches, but at an upper tidal height similar to Patch \# 3 (Fig. 1, Table 1). Patches \#1 and \# 3 were $10 \mathrm{~m}$ apart at their closest points, but had almost no

- However, Woodin (1977) has described this species in Washington living head downward in vertical tubes.

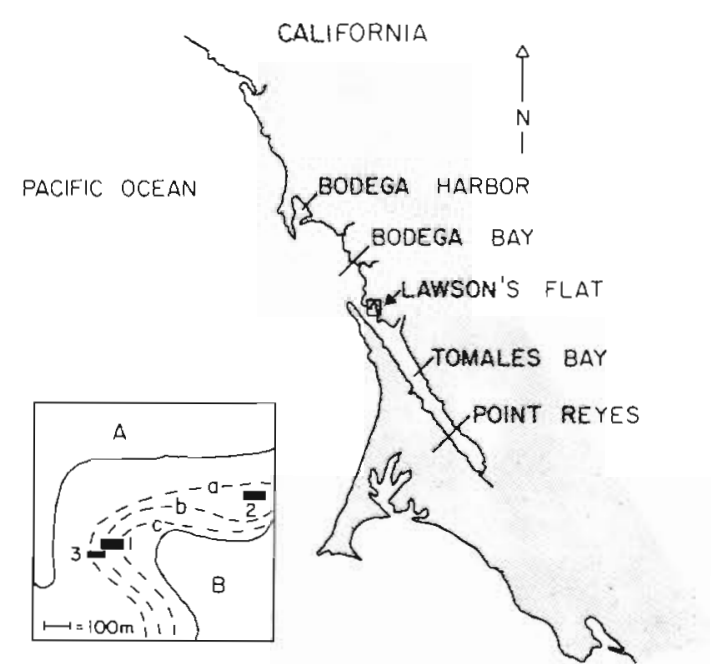

Fig. 1. Study area. Insert shows the three Study Sites $(1,2,3)$ on Lawson's Flat, sand dunes (A), Tomales Bay at low tide $(B)$, and tidal height contours: $\mathrm{a}=+0.91 \mathrm{~m}, \mathrm{~b}=+0.61 \mathrm{~m}$, $\mathrm{c}=+0.03 \mathrm{~m}$

overlap with respect to tidal height. The range of tidal inundation times varied from approximately $80 \%$ per week in the lower part of Patch \# 1 to as little as $35 \%$ per week in the upper part of Patch \# 3 (Weinberg, 1978).

Spionid polychaetes are commonly found on Lawson's Flat (Howege, 1976) as well as on most softsubstrates in other marine geographical areas (Blake, 1975; Whitlatch, 1977). Though of smaller body size, adult individuals of this family have important lifestyle characteristics (tube-dwelling and deposit-feeding) in common with Axiothella rubrocincta. Unlike $A$. rubrocincta, spionids inhabit vertical tubes and use palps (anterior appendages) in order to feed from the sediment-water interface.

\section{METHODS}

\section{Axiothella rubrocincta - Spionid Densities and Distributions}

Sampling was conducted on the exposed sandflat at low tide. Four permanent stakes were placed in a rectangle around the outside of each Axiothella rubrocincta patch. Patch tidal heights were determined by repeatedly comparing high and low water marks on the sandflat with tide table predictions.

Axiothella rubrocincta patch area and density of feeding individuals were estimated monthly for 13 months, using a surface defecation mound count. Each feeding individual produces one surface sediment 
mound which surrounds the tube's defecation aperture (Kudenov, 1971). Feeding is a daily activity (Weinberg, 1978). During sampling, the left and right edges of each patch were mapped (noting the absence of all mounds) at $6 \mathrm{~m}$ intervals for their entire lengths by laying a transect line across the patch. Surface counts of A. rubrocincta mounds were made within patches using a $0.25 \mathrm{~m}^{2}$ quadrat. Between June, 1975, and February, 1976, quadrat samples were taken on a grid. Subsequently, quadrats were located using a table of random numbers. No measurements were taken in Patch \# 1 in September, 1975, due to extensive algal coverage.

The macrofauna inside and around the Axiothella rubrocincta patches was sampled for a 1 year period using a hand-operated PVC suction core, $10 \mathrm{~cm}$ in diameter and $20 \mathrm{~cm}$ deep. Samples were sieved through a 0.5 -mm screen and preserved in $7 \%$ formalin. The macrofauna was identified to species and preserved in $70 \%$ alcohol. Only the spionid polychaete data are presented in detail here (see Weinberg, 1978. for further community data). Although there are differences between spionid species (Robert Whitlatch, personal communication), the data to be presented indicate that substrate resource utilization by the family Spionidae on Lawson's Flat is included within that of Axiothella rubrocincta. Therefore, I treat the family Spionidae as one guild (sensu Root, 1967) interacting with $A$. rubrocincta.

The sampling dates were June, September, December, 1975, and March and June, 1976. Each study site is defined as one Axiothella rubrocincta patch and its outer surrounding edge. The sampling design employed was a three-way analysis of variance (ANOVA) with nesting and replication. The ANOVA treatments were study sites (3), sampling times (5), and within or outside of an Axiothella rubrocincta patch (2). Stratified random sampling was performed by dividing each patch into an upper and lower half (the nesting) and taking 3 replicate samples in each half. For each of the 'Within Patch' samples, an 'Outer' sample was taken 1-2 $\mathrm{m}$ beyond the edge of the patch from the left and right sides at the same tidal height. Three-way ANOVAs were performed on the estimates of spionid densities (a $\log [x+1]$ data transformation was performed in order to satisfy assumptions of ANOVA). One ANOVA involved data collected outside (left) and inside of the Axiothella rubrocincta patches, while the other involved data from the outside (right) and inside. Two ANOVA comparisons were advantageous because the spionid density 'Within' the Axiothella rubrocincta patches could be compared with two distinct 'Outside Patch' habitats. In addition, two a priori comparisons (Sokal and Rohlf, 1969) were planned for each ANOVA in order to test the effect of tidal height differences (Study Site \#1 vs. \#2 and \#3) and distance (Study Site \#2 vs. \#1 and \#3) between study sites.

\section{Axiothella rubrocincta - Resource Utilization and Substrate Modification}

The response of four Axiothella rubrocincta living in a submerged simulated sandflat $(26 \times 36 \times 18 \mathrm{~cm}$ deep container) to changes in surface OMA abundance was observed from March 11 to May 24, 1977. Tenminute observations were made three times per week on worm feeding behavior. Tube position was noted during each observation. All visible OMA were pipetted from the worm feeding funnels on May 10 to determine the effect of its absence on worm feeding behavior and tube position.

Surface OMA abundance was measured from laboratory cultures which had contained Axiothella rubrocincta for a 10 week period (May-July, 1976). Randomly chosen adult $A$. rubrocincta were initially placed in the sediment-filled containers $(25 \mathrm{~cm}$ deep) in 4 treatment densities commonly occurring in the study area $\left(0,24,72,144\right.$ feeding individuals $\left.\mathrm{m}^{-2}\right)$. There were 4 replicates per treatment. Sediment used in the experiment was initially collected from an Axiothella rubrocincta patch with a density of approximately 48 feeding individuals $\mathrm{m}^{-2}$. This sediment was taken from the upper $5 \mathrm{~cm}$ and contained the natural fauna (this depth does not catch $A$. rubrocincta). At the end of 10 weeks, one $3-g$ sediment sample was randomly collected from the top $1 \mathrm{~cm}$ of each treatment container and was treated with a Periodic Acid Schiff (PAS) stain (Whitlatch and Johnson, 1974). PAS stains most protein-carbohydrate, glycogen, and starch complexes red (Humason, 1967) facilitating subsequent compositional descriptions of individual, randomly chosen particles (50 random particles per sample, 4 samples per $A$. rubrocincta treatment). Comparisons using orthogonal polynomials (Keppel, 1973) were made to detect linear and exponential changes in OMA abundance due to increased $A$. rubrocincta density.

Surface OMA abundance was also measured from random field samples ( 3 replicates) collected at the mid-tidal point of each Axiothella rubrocincta patch and on each 'Outside Patch' edge (July, 1978). The samples were collected and treated as described above, although 4 subsamples, consisting of 50 random particles each, were described per replicate sample. Two-level nested ANOVA comparisons were made to detect differences in relative \% OMA both between patches and between each patch and its 'Outer' edges (a $\log [x+1]$ data transformation was performed to fulfill assumptions of ANOVA). 
For general 'sediment type' categorization, two 150 -g sediment samples were taken from the top $3 \mathrm{~cm}$ of the mid-tidal point of each Axiothella rubrocincta patch (June, 1976) and were dry-sieved through a Tyler screen series in $0.5 \Phi$ increments.

\section{Spionid Resource Utilization and Interactions with Axiothella rubrocincta}

Pseudopolydora paucibranchiata was chosen as a locally common (Blake and Woodwick, 1975) spionid for detailed study. The gut contents of individual $P$. paucibranchiata ( $\mathrm{n}=6$ ) from Lawson's Flat were qualitatively analyzed for the presence of OMA (June, 1977). One hundred randomly chosen mineral particles were measured following treatment of the pooled gut contents with warm $\mathrm{H}_{2} \mathrm{O}_{2}$ to destroy the organic material which aggregates the particles (Johnson, 1974). OMA were collected at the same time from the substrate surface, using an eye dropper, for quantitative and qualitative comparison with the gut contents. In the laboratory the intact OMA were also treated with $\mathrm{H}_{2} \mathrm{O}_{2}$, and 100 of the newly freed mineral particles were measured.

The feeding behavior of tube-dwelling Pseudopolydora paucibranchiata (10 worms per $45-\mathrm{mm}$ diameter dish) was observed (June, 1977) in dishes containing varied concentrations of OMA and sediment. Observations were made for $1 \mathrm{~h} \mathrm{~d}^{-1}$ for 15 consecutive days. The treatments ranged from total coverage of the surface by a thin OMA mat $(0.5 \mathrm{~mm})$ to one in which no OMA were detectable by eye.

The anterior ends of spionid tubes collected from muddy and sandy habitats (June, 1975-June, 1976) were analyzed qualitatively for the presence of OMA. A quantitative PAS analysis, which describes individual OMA and mineral particles, was not possible because worms cement their tubes by a mucus secretion. Twenty-five tubes, involving six species of spionids were investigated. One hundred randomly chosen mineral particles from two Pseudopolydora paucibranchiata tubes were measured following $\mathrm{H}_{2} \mathrm{O}_{2}$ treatment.

Spionid tube-building behavior was studied in the laboratory (June, 1977) by placing tubeless individuals of Pseudopolydora paucibranchiata on three treatment substrates (S) ( $n=12,4$ runs/substrate with 3 worms/ run). Each of the walled dishes (45 $\mathrm{mm}$ in diameter) contained a $5 \mathrm{~mm}$ deep substrate. Treatments $\mathrm{S} 1$ and $\mathrm{S} 2$ contained oven-dried sediment combined from the three Axiothella rubrocincta patches and having the grain-size distribution shown in Figure 6. OMA was added to treatment $\mathrm{S} 2$ by suspending a large amount of OMA in sea water and pipetting the mixture. After allowing the aggregates to settle in the vertical pipette for $1 \mathrm{~min}, 3 \mathrm{ml}$ were released into the S2 dish. S2 had visible clumps of OMA on the sediment surface, but they were not abundant enough to form a continuous mat. Treatment S3 consisted only of OMA with no Axiothella rubrocincta patch sediment.

Tube-dwelling adult Pseudopolydora paucibranchiata $(n=8)$ were taken from the field and placed in sediments (from Axiothella rubrocincta patches) with experimental densities of A. rubrocincta $(0,160$, or 320 individuals $\mathrm{m}^{-2}$ ) in order to study spionid survival in sympatry with $A$. rubrocincta. Each treatment density had 5 replicates. No spionids were present in the sediment initially. Many adult $P$. paucibranchiata tubes contained eggs at this time (July, 1977; personal observation). All treatment containers were submerged in an unfiltered sea-water bath for the duration of the experiment. After 1 month the spionid tubes visible by eye were collected, their condition noted, and the live inhabitants identified to species.

Table 1. Axiothella rubrocincta. Mean patch areas, densities of feeding individuals, and patch tidal heights for three patches and five sampling periods. The defecation mound count method was employed for area-density estimates $(\bar{X}=$ mean, $S=\operatorname{standard}$ deviation; $N=$ sample size)

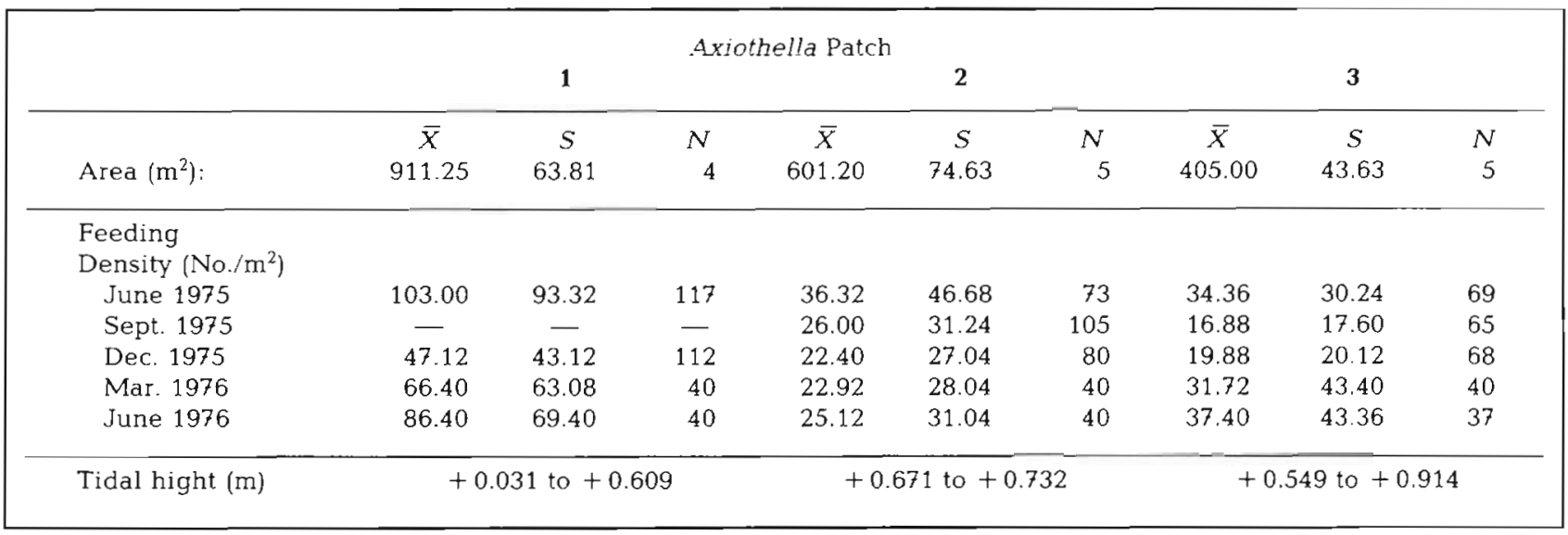




\section{The Spionid Predator Escape Response}

Six juvenile (approximately $50 \mathrm{~mm}$ long) flatfish Parophrys vetulus and one juvenile sculpin Leptocottus armatus were placed with 20 tube-dwelling $P_{\text {seu- }}$ dopolydora paucibranchiata in an aquarium $(80 \mathrm{~cm}$ long, $30 \mathrm{~cm}$ wide). The fish had been fed mussels, pieces of which were lying about in excess during the observations. The number of fish attacks on spionids and success rates were measured during 1-h observation periods on 2 consecutive days (July, 1977).

\section{RESULTS}

\section{Axiothella rubrocincta - Spionid Densities and Distributions}

Each of the Axiothella rubrocincta patches persisted for the duration of the study without gross changes in patch area or location (Weinberg, 1978). Mean patch areas, density of actively feeding $A$. rubrocincta, and patch tidal heights are summarized in Table 1. Patch \# 1 was almost twice the area of the other patches and

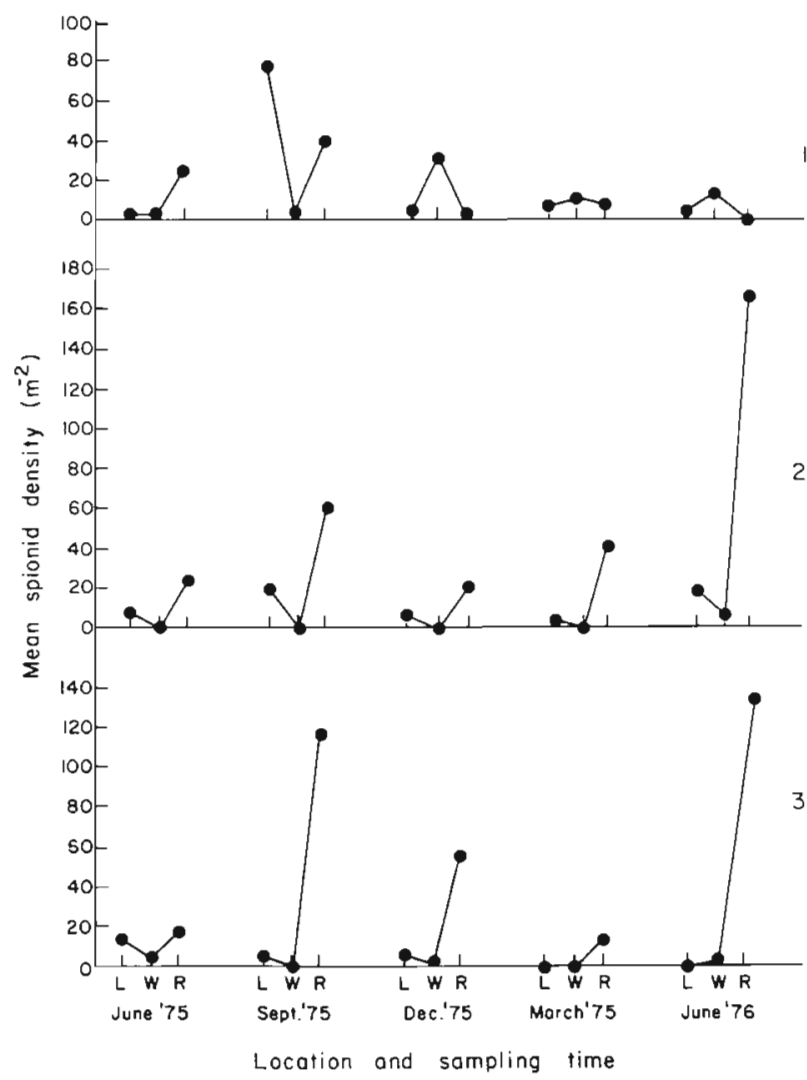

Fig. 2. Mean spionid densities $(n=6)$ estimated at Study Sites 1,2 , and 3 at five sampling times. Densities were estimated to the outside left (L) and right $(R)$ and from within (W) each Axiothella rubrocincta patch consistently had a higher monthly density of feeding A. rubrocincta. Within a given patch several high and low density areas occurred.

A list of species collected within the patches is presented in Table 2.

The following species of spionid polychaetes were less abundant 'Within' Axiothella rubrocincta patches compared with 'Outer Edge' samples taken at equivalent tidal heights: Boccardia proboscidea Hartman, Polydora ligni Webster, Pseudopolydora kempi Southern, Pseudopolydora paucibranchiata Okuda, Pygospio elegans Claparede, Rhynchospio arenicola Hartman, Spiophanes missionensis Hartman, and Streblospio benedicti Webster. The mean spionid densities estimated to the left of, to the right of, and within each of the three Axiothella rubrocincta patches for each sampling time are presented in Figure 2. The mean

Table 2. List of species collected within Axiothella rubricincta patches on Lawson's Flat from June, 1975, to June, 1976. Numbers: specific patch(es) in which the species was collected

$\begin{array}{lr}\text { Bivalvia (Mollusca) } & \\ \text { Gemma gemma } & 123 \\ \text { Macoma nasuta } & 13 \\ \text { Macoma secta } & 13 \\ \text { Transennella tantilla } & 123 \\ \text { Transennella sp. } & 123 \\ \text { Protothaca staminea } & 13\end{array}$

Crustacea (Arthropoda)

Allorchestes angusta $\quad 123$

Ampithoe valida 123

Aorides columbiae 1

Corophium acherusicum-insidiosum-uenoi 123

Corophium brevis 12

Crangon franciscorum

Eohaustorius sp.

Hemigrapsus oregonensis

Leptochelia dubia

Nebalia pugettensis

Paraphoxus milleri

Paraphoxus epistomus

Paraphoxus tridentatus

13

23

Polychaeta (Annelida)

Anaitides williamsi 1

Capitella capitata 13

Eteone californica 123

Glycinde armigera 123

Haploscoloplos elongatus 123

Lumbrineris zonata $\quad 123$

Mediomastus califomiensis $\quad 123$

Notomastus tenuis $\quad 13$

Nephtys caecoides 123

Platynereis bicanaliculata 123

Polydora ligni 13

Pseudopolydora paucibranchiata 1

Pseudopolydora kempi 13

Pygospio elegans 2 
Table 3. Upper and lower confidence intervals (C.I.) about mean spionid densities (no. $\mathrm{m}^{-2}$ ) (Fig. 2) estinated at three sample sites over five sampling times. Densities were estimated to the outside left (L) and right (R) and from within (W) each Axiothella rubrocincta patch. C.I.'s are asymmetric about the means (Fig. 2$)$ due to previous $\log (x+1)$ data transformation

\begin{tabular}{|c|c|c|c|c|c|c|c|}
\hline \multirow[t]{2}{*}{ Sample site } & \multirow[t]{2}{*}{$95 \%$ C.I. } & \multirow[t]{2}{*}{ Location } & \multicolumn{5}{|c|}{ Sampling time } \\
\hline & & & 1 & 2 & 3 & 4 & 5 \\
\hline \multirow{7}{*}{1} & \multirow{3}{*}{ Upper } & L & 14.99 & 2116.35 & 139.73 & 139.73 & 22.04 \\
\hline & & W & 14.99 & 139.73 & 336.92 & 155.36 & 185.14 \\
\hline & & $\mathrm{R}$ & 736.94 & 655.84 & 14.99 & 101.85 & 0.00 \\
\hline & & & & & & & \\
\hline & \multirow{3}{*}{ Lower } & $\mathrm{L}$ & 0.34 & 2.76 & 0.18 & 0.18 & 0.29 \\
\hline & & W & 0.34 & 0.18 & 2.76 & 0.37 & 0.87 \\
\hline & & $\mathrm{R}$ & 0.83 & 2.42 & 0.34 & 0.40 & 0.00 \\
\hline \multirow{7}{*}{2} & \multirow{3}{*}{ Upper } & $\mathrm{L}$ & 31.11 & 352.57 & 139.73 & 14.99 & 397.35 \\
\hline & & W & 0.00 & 0.00 & 0.00 & 0.00 & 74.75 \\
\hline & & $\mathrm{R}$ & 585.01 & 1345.99 & 377.26 & 667.11 & 2054.29 \\
\hline & \multirow{4}{*}{ Lower } & & & & & & \\
\hline & & $\mathrm{L}$ & 1.03 & 0.78 & 0.18 & 0.34 & 0.81 \\
\hline & & W & 0.00 & 0.00 & 0.00 & 0.00 & 0.43 \\
\hline & & $\mathrm{R}$ & 0.85 & 2.56 & 0.82 & 2.43 & 13.64 \\
\hline \multirow{7}{*}{3} & \multirow{3}{*}{ Upper } & $\mathrm{L}$ & 234.30 & 74.75 & 74.75 & 0.00 & 0.00 \\
\hline & & W & 139.73 & 0.00 & 14.99 & 0.00 & 22.04 \\
\hline & & $\mathrm{R}$ & 234.30 & 1133.93 & 1153.14 & 185.14 & 1729.89 \\
\hline & & & & & & & \\
\hline & \multirow{3}{*}{ Lower } & $\mathrm{L}$ & 0.87 & 0.43 & 0.43 & 0.00 & 0.00 \\
\hline & & W & 0.18 & 0.00 & 0.34 & 0.00 & 0.29 \\
\hline & & $\mathrm{R}$ & 0.87 & 11.90 & 2.58 & 0.87 & 10.52 \\
\hline
\end{tabular}

spionid density 'Within' Axiothella rubrocincta patches \# 2 and \# 3 was less than the 'Outside Patch' density in $90 \%$ of the comparisons $(n=20)$ of outside (left) vs. within and outside (right) vs. within. In contrast, no consistent trend occurred at Patch \#1. The variances about the mean spionid densities are large and the $95 \%$ confidence intervals for each mean $(n=$ 6) are given in Table 3.

Table 4. Results of two $(a, b)$ three-way ANOVA's with nesting among sets of replicates. ANOVA 'a' involved data from outside (left) and from within Axiothella rubrocincta patches. ANOVA ' $b$ ' involved data from outside (right) and from within patches. Each study site included one A. rubrocincta patch and its outer surrounding edge. ns: not significant

\begin{tabular}{|c|c|c|}
\hline \multirow{2}{*}{ Source of variation } & \multicolumn{2}{|c|}{ ANOVA } \\
\hline & $\mathrm{a}$ & $b$ \\
\hline \multicolumn{3}{|l|}{ Main effects } \\
\hline Study site (A) & $p<0.05$ & ns \\
\hline Sampling time (B) & ns & ns \\
\hline Within-outside Patch (C) & $p<0.05$ & $p<0.001$ \\
\hline \multicolumn{3}{|l|}{ First-order interactions } \\
\hline$A \times B$ & ns & ns \\
\hline$A \times C$ & ns & $p<0.001$ \\
\hline $\mathrm{B} \times \mathrm{C}$ & ns & ns \\
\hline \multicolumn{3}{|l|}{ Second-order interaction } \\
\hline $\mathrm{A} \times \mathrm{B} \times \mathrm{C}$ & ns & ns \\
\hline Among replicates & $p<0.05$ & $p<0.01$ \\
\hline
\end{tabular}

The results of the first three-way ANOVA, which involved spionid densities estimated from outside (left) and within the Axiothella rubrocincta patches at all three study sites, are presented in Table 4a. Two of the main effects (A and C) were significant, in addition to the nesting which occurred among sets of replicates taken in the upper and lower halves of each study site. Significantly lower spionid densities occurred 'Within' the Axiothella rubrocincta patches (Main Effect $C$; determined by comparison of the 'Within' and 'Outside group totals). In order to determine which study sites had significantly different spionid densities (Main Effect A), two a priori comparisons were performed (Table 5). Study Site \# 1, located lowest in the intertidal zone, had significantly greater spionid density than the other study sites. The density estimate at Study Site \#2, which was distant from the other sites, was not significantly different than that of other sites.

The results of the second three-way ANOVA, which

Table 5. Results of two a priori comparisons (from ANOVA Table 3a, significant Main Effect A) of estimated spionid densities among Study Sites 1, 2, and 3

\begin{tabular}{|ccc|}
\hline Comparison & Significance & Main physical difference \\
\hline 1 vs. 2 and 3 & $p<0.05$ & Tidal height \\
2 vs. 1 and 3 & ns & Broad separation \\
\hline
\end{tabular}


involved spionid densities estimated from outside (right) and within the Axiothella rubrocincta patches, are presented in Table $4 \mathrm{~b}$. One of the Main Effects (C) was significant. In addition, one first-order interaction $(A \times C)$ and the nesting among sets of replicates within study sites were significant. The significant nesting term may be the result of factors associated with tidal height within study sites. As in the first ANOVA, significantly lower spionid densities were estimated to occur 'Within' the Axiothella rubrocincta patches (Main Effect $C$, see Fig. 2). The meaning of the significant $\mathrm{AxC}$ interaction is that the estimated spionid density from either the 'Outside (right)' or from 'Within' an Axiothella rubrocincta patch (Main Effect C) was dependent upon the Study Site (Main Effect A) sampled. This interaction is demonstrated in Figure 3. Study Site \# 1 had similar spionid densities 'Within' and 'Outside (right)' the $A$. rubrocincta patch, while spionid densities at Study Sites \# 2 and \# 3 decreased sharply 'Within' the A. rubrocincta patches.

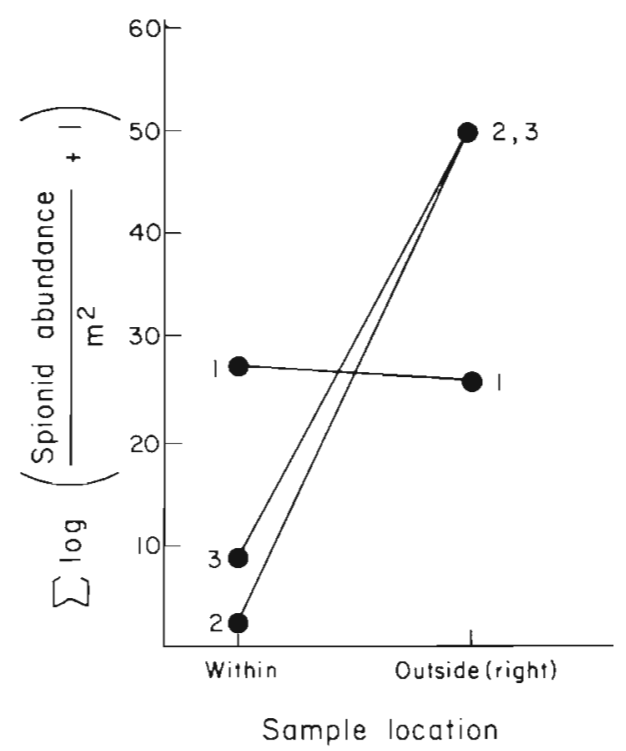

Fig. 3. Significant interaction (ANOVA, Table $4 \mathrm{~b}$ ) between Study Site $(1,2,3) \times$ Sample Location (within, outside Axiothella rubrocincta patch) with respect to spionid density

\section{Axiothella rubrocincta - Resource Utilization and Substrate Modification}

Axiothella rubrocincta feeding biology was studied in order to examine the apparent relationship of $A$. rubrocincta and spionid distributions. Approximately $17 \%$ (5 of 30 observations) of the time in the simulated sandflat, individuals were observed extending their heads and anterior segments $2-4$ cm out of the tube oral aperture. These worms were selectively feeding on the reddish-brown OMA within and beyond the upper edges of their funnels (OMA collect on sediment surfaces and particularly in depressions such as $A$. rubrocincta funnels; see Kudenov, 1971). The feeding resulted in a distinct color change (reddish-brown to gray) in the sediment surface. Feeding ceased in an area once it had been thoroughly vacuumed. From March 11 to May 10, individuals fed in an area for approximately 40 days before switching to a new feeding location. Worms increased this switching rate to every 9 days when I removed OMA from the feeding funnels. Furthermore, experimental A. rubrocincta relocated their entire feeding apertures to areas of higher OMA content within 10 days following OMA removal. In addition to OMA, individuals ingested large amounts of mineral particles (mean particle size: $190 \mu \mathrm{m})$.

There existed in the laboratory an inverse relationship between density of feeding Axiothella rubrocincta and OMA abundance (Fig. $4 \mathrm{a}$, b) which resulted from this polychaete's reworking. OMA can be separated into two categories based upon compactness: (1) OMA which are loosely bound, and (2) $\mathrm{OMA}_{2}$ which are tightly compacted. The significant treatment trends of Figure 4, relating relative aggregate and mineral particle abundance to worm density, are given in Table 6 . $\mathrm{OMA}_{1}$ abundance decreased exponentially (the linear trend was also significant) with linearly increasing $A$. rubrocincta density, with the greatest change in $\mathrm{OMA}_{1}$ occurring at very low worm density (0-24 individuals $\mathrm{m}^{-2}$; Fig. 4a). Loose aggregates were virtually nonexistent in those treatments with 72 or more $A$. rubrocincta $\mathrm{m}^{-2}$. $\mathrm{OMA}_{2}$ values remained constant and high at low $A$. rubrocincta densities, but decreased exponentially at higher worm densities ( $\geq 72$ individuals

Table 6. Results of the orthogonal analysis for the relative abundances of OMA and mineral particles found in containers with increasing Axiothella rubrocincta densities. The 'groups' source is subdivided into 'linear' and 'quadratic' components. Significance implies that the data has been fitted to a particular trend. ns: not significant

\begin{tabular}{|ccc|}
\hline Sediment type & Source & F \\
\hline & Groups & $p<0.001$ \\
OMA $_{1}$ & Linear & $p<0.001$ \\
& Quadratic & $p<0.001$ \\
& Groups & $p<0.001$ \\
& Linear & $p<0.001$ \\
OMA $_{2}$ & Quadratic & $p<0.001$ \\
& Groups & $p<0.001$ \\
& Linear & $p<0.001$ \\
Mineral & Quadratic & $\mathrm{ns}$ \\
& &
\end{tabular}




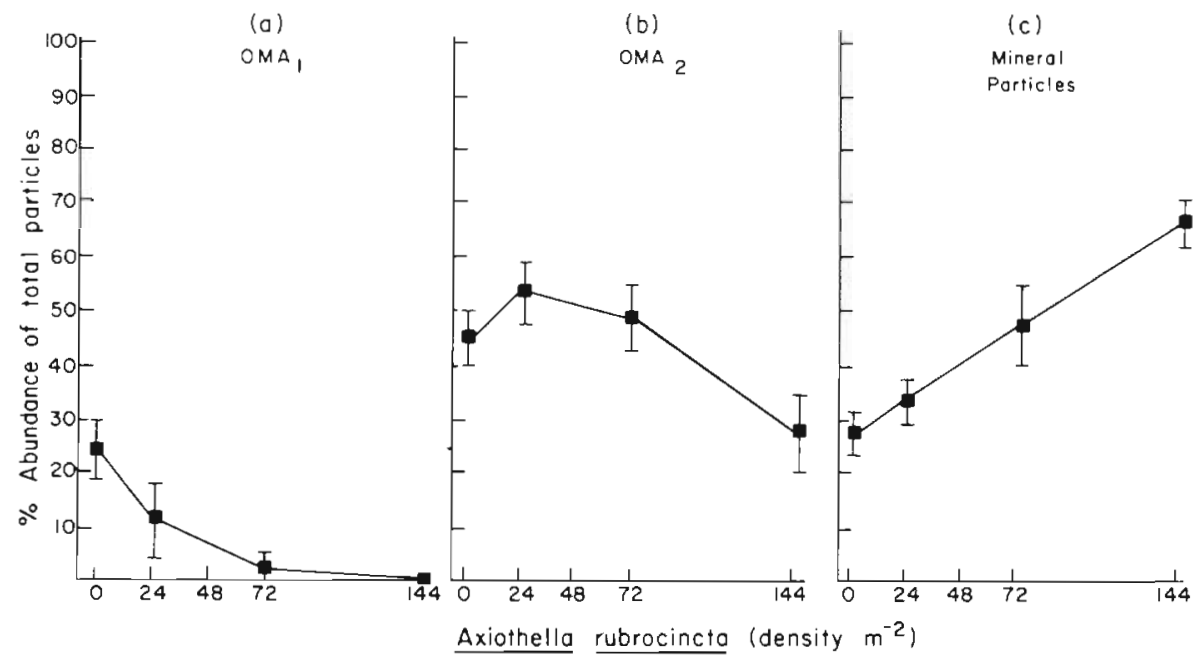

Fig. 4. Changes in substrate composition caused by different experimental densities of feeding Axiothella rubrocincta. OMA refers to loosely bound aggregates. OMA 2 refers to compact aggregates. Vertical bars are $95 \%$ confidence intervals about the means $(n=4)$

$\mathrm{m}^{-2}$; Fig. 4b). The depletion of most OMA at high $A$. rubrocincta densities resulted in clean sand (predominantly quartz; Fig. 4c).

Field observations confirmed the Axiothella rubrocincta depletion of OMA on Lawson's Flat. Mean relative percentages of $\mathrm{OMA}_{1}$ clearly increased on the 'Outside Patch' edges (left and right) of $A$. rubrocincta Patches \# 2 and \# 3 (Table 7 ). Relative $\%$ OMA was as low as $1.17 \%$ and $3 \%$ within Patches \#2 and \# 3 . It should be noted that the OMA quantification method is somewhat inappropriate for samples of very high $\mathrm{OMA}_{1}$ content (e.g. outside of Patch \#1). At lower intertidal stations aggregates tended to fragment and

Table 7. Sediment characteristics at three Axiothella rubrocincta patches. Sample locations were to the outside left (L), right $(\mathrm{R})$, and within (W) each patch. Relative \% OMA, from PAS analysis, is a grand mean of three replicate means. The mean of each of the replicates was of four subsample means. $\%$ silt-clay in sediment is from dry-sieving analysis $(\overline{\bar{X}}=$ grand mean, $\bar{X}=$ mean, $S=$ standard deviation, $N=$ sample size)

\begin{tabular}{|c|c|c|c|c|c|c|c|}
\hline \multirow[t]{2}{*}{ Patch\# } & \multirow[t]{2}{*}{$\begin{array}{l}\text { Sample } \\
\text { location }\end{array}$} & \multicolumn{3}{|c|}{$\begin{array}{l}\text { Relative } \% \mathrm{OMA}_{1} \\
\text { in sediment }\end{array}$} & \multicolumn{3}{|c|}{$\begin{array}{l}\% \text { Silt-clay } \\
\text { in sediment }\end{array}$} \\
\hline & & $\overline{\bar{X}}$ & $S$ & $N$ & $\bar{X}$ & $s$ & $N$ \\
\hline \multirow{3}{*}{1} & L & - & - & - & - & - & - \\
\hline & W & 42.17 & 4.75 & 3 & 2.45 & 0.64 & 2 \\
\hline & $\mathrm{R}$ & - & - & - & - & - & - \\
\hline \multirow{3}{*}{2} & $\mathrm{~L}$ & 30.33 & 6.03 & 3 & - & - & - \\
\hline & W & 1.17 & 1.16 & 3 & 0.45 & 0.21 & 2 \\
\hline & $\mathrm{R}$ & 25.50 & 8.00 & 3 & - & - & - \\
\hline \multirow{3}{*}{3} & $\mathrm{~L}$ & 12.33 & 4.03 & 3 & - & - & - \\
\hline & $w$ & 3.00 & 3.04 & 3 & 1.30 & 0.14 & 2 \\
\hline & $\mathrm{R}$ & 32.83 & 11.90 & 3 & - & - & - \\
\hline
\end{tabular}

although stained flocculent material clearly dominated the samples, individual aggregates could not be counted. Results of 6 ANOVAs (Fig. 5) concerning OMA relative abundance at the field study sites demonstrate that (a) there was significantly less $\mathrm{OMA}_{1}$ within $A$. rubrocincta Patches \#2 and \#3 than on their 'Outside' edges ( 4 horizontal arrows) and that (b) among patches, both \#2 and \# 3 contained significantly less $\mathrm{OMA}_{1}$ than \#1 (2 vertical arrows).

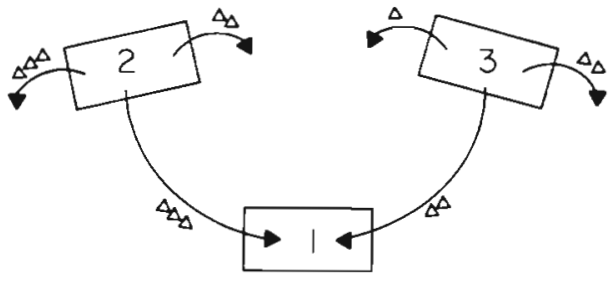

Fig. 5. Results of six, two-level nested ANOVAs. The dependent variable was the $\%$ relative $\mathrm{OMA}_{1}$ abundance in sediment. The data were $\log (x+1)$ transformed. Each numbered box represents an Axiothella rubrocincta patch $(1,2,3)$ where $\mathrm{OMA}_{1}$ samples were collected ('within', 'outside'). Each ANOVA is represented by an arow (pointing at the locality with significantly greater $\mathrm{OMA}_{1}$ ) with triangles (significance level: $\Delta=p<0.05, \Delta \Delta=p<0.01, \Delta \Delta \Delta=p<0.001$ )

Results of the dry-sieved sediments (Fig. 6) categorize Axiothella rubrocincta patches as 'sands'. Although over $90 \%$ by weight of the mineral particles were smaller than $250 \mu \mathrm{m}(2.0 \varnothing)$, only $1.5 \%$ of the sediments were in the silt-clay range of less than $88 \mu \mathrm{m}$ $(3.5 \varnothing)$. A significant difference exists in $\%$ silt-clay abundance between $A$. rubrocincta Patches \# 1 and \# 2 ( $\mathrm{p}<0.05$, t-test; Table 7 ). The $\%$ silt-clay in Patch \#1 is greater than that in other patches. 


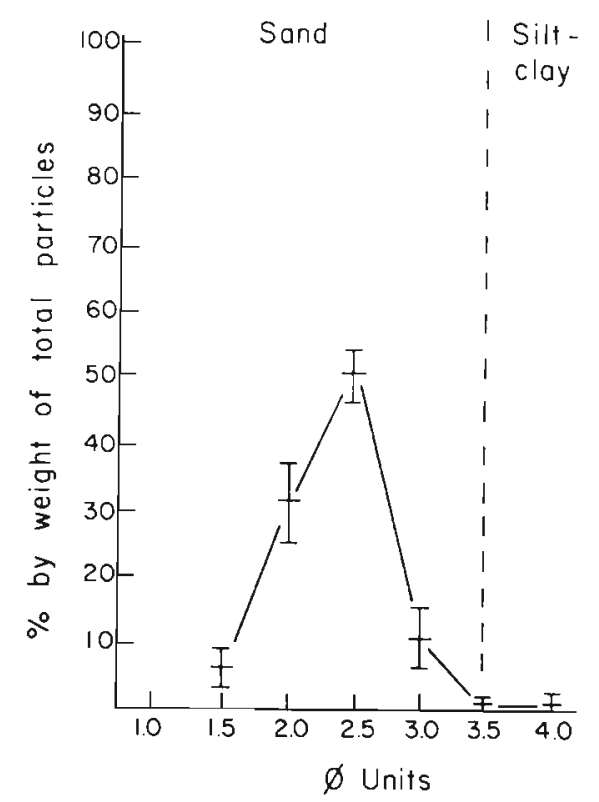

Fig. 6. Particle-size distribution by weight in Axiothella rubrocincta Patches 1, 2, and 3 . Two samples were collected from each patch. Vertical bars are $95 \%$ confidence intervals about the means

\section{Spionid Resource Utilization and Interactions with Axiothella rubrocincta}

Since it was found that Axiothella rubrocincta feeding modified the surficial characteristics of the sediment, information was collected in order to see what influence substrate modification had on surface-feeding spionid polychaetes. Pseudopolydora paucibranchiata was chosen as a common, local spionid for detailed examination. Gut contents of 6 P. paucibranchiata analyzed did not appear qualitatively different from the OMA ${ }_{1}$ found on the nearby substrate or in the A. rubrocincta sediment modification analysis. Furthermore, over $70 \%$ of the mineral particles extracted from both the gut contents and the field $\mathrm{OMA}_{1}$ sample were $\geq 16 \mu \mathrm{m}$ in length (Table 8 ).

Observations on the feeding behavior of Pseudopolydora paucibranchiata demonstrated that OMA was selectively chosen in all OMA densities. In substrates with virtually no OMA, individuals $(n=10)$ increased the area searched by extending out of their tubes. This activity repeatedly caused the prostomial (head) region to be exposed. In treatment substrates with large quantities of $\mathrm{OMA}_{1}$, individuals $(n=10)$ collected and drew the aggregates into their tubes solely with their palps. Heads were not exposed during this activity. Occasionally worms piled or attached large pieces of OMA around their tubes. Other individuals within reach were seen taking these aggregates for themselves; however, no intraspecific aggressive encounters were observed. The result of these activities was a concentration of OMA around the $P$. paucibranchiata tubes, which left much of the substrate free of aggregates.

The anterior ends of the 25 spionid tubes (representing Boccardia proboscidea, Polydora ligni, Pseudopolydora kempi, P. paucibranchiata, Pygospio elegans, and Spiophanes missionensis) were predominantly composed of OMA. Two main types of tubes were recognized, those occurring in muddy and those in sandy habitats. The exterior portions of tubes in muddy areas were primarily composed of $\mathrm{OMA}_{1}$ while tubes in sandy habitats consisted of mica, quartz, and $\mathrm{OMA}_{1}$. The mean lengths of mineral particles extracted from the two $P$. paucibranchiata tubes were $29 \mu \mathrm{m}$ and 18 $\mu \mathrm{m}$, approximately the size of mineral particles found within $\mathrm{OMA}_{1}$ (see Table 8).

Since the spionids on Lawson's Flat construct tubes from $\mathrm{OMA}_{1}$, I experimentally evaluated its effect on spionid tube-building rate. Surface tube-building rate by Pseudopolydora paucibranchiata $(n=12)$ increased with $\mathrm{OMA}_{1}$ relative abundance (Table 9). The fastest and least variable rates occurred in the pure $\mathrm{OMA}_{1}$ (Table 9, S3; see Blake and Woodwick, 1975, for a similar estimate). Tube-building rates of individuals in Axiothella rubrocincta Patch Substrates S1 and S2 differ markedly because of the addition of $\mathrm{OMA}_{1}$ in $\mathrm{S} 2$. It was possible for individuals to build tubes in the pure A. rubrocincta Patch Sediment S1, though at a very slow rate. These individuals were observed collecting the scarce $O M A_{1}$ and incorporating it into their tubes with mineral particles. S2 individuals were observed to selectively gather $\mathrm{OMA}_{1}$ and to reject the heavier mineral particles. Quartz, mica, and shell fragments were channelled in with the palps, but were usually rejected at the prostomium.

Pseudopolydora paucibranchiata survival was in-

Table 8. Percent of mineral particles in the gut contents of Pseudopolydora paucibranchiata and in an OMA, sample from the sediment surface

\begin{tabular}{|lccccccccc}
\hline Source of particles & & \multicolumn{5}{c}{ Particle size $(\mu \mathrm{m})$} \\
& $1-8$ & $9-16$ & $17-24$ & $25-32$ & $33-40$ & $41-48$ & $49-56$ & $>56$ \\
\hline Gut contents & 39 & 42 & 8 & 2 & 4 & 1 & 4 \\
OMA $_{1}$ & 37 & 36 & 12 & 4 & 3 & 3 & 3 & 2 \\
\hline
\end{tabular}


Table 9. Tube-building rates of Pseudopolydora paucibranchiata measured in sediment types containing increasing percentages of organic-mineral aggregates (OMA)

\begin{tabular}{ccc|}
$\begin{array}{c}\text { Treatment } \\
\text { substrate }\end{array}$ & $\%$ OMA & $\begin{array}{c}\text { Range of building } \\
\text { rates }\left(\mu \mathrm{m} \text { min }^{-1}\right)\end{array}$ \\
\hline 1 & 0 & $37.5-87.5$ \\
2 & $\downarrow$ & $300.0-375.0$ \\
3 & 100 & $375.0-387.5$ \\
\hline
\end{tabular}

versely related to density of feeding Axiothella rubrocincta (Table 10). After 4 weeks, $80 \%$ (8 of 10) of the samples containing $A$. rubrocincta had less than the initial sympatric spionid density (8); the majority (5 of 8 samples) had $\leq 3$ worms remaining. Blackened and decomposing spionid tubes were found in all of the samples containing $A$. rubrocincta, although none were found in any of the control samples. It was not possible to distinguish $P$. paucibranchiata recruits from the original adults because of the rapid growth rates of the newly settled juveniles (see Blake and Woodwick, 1975). It can be seen that spionid larval survival was significantly greater when no A. rubrocincta was present, by taking into account the original number of spionid adults. P. kempi larvae, all of which entered the experimental system via the sea water inlet, had significantly greater ( $p<0.05, t$-test) settlement when A. rubrocincta was not present (Table 10).

Table 10. Changes in the number of two spionid species with increasing Axiothella rubrocincta density. Eight Pseudopolydora paucibranchiata were added to each replicate at the start of the experiment (time $e_{0}$ ). Initial $P$. kempi abundance was zero as they settled during the experiment from the unfiltered sea water system

\begin{tabular}{|lccc|}
\hline \multicolumn{1}{|c}{ Sympatric spionid } & & $\begin{array}{c}\text { A. rubro- } \\
\text { cincta } \\
\text { density } \\
\text { (no } \mathrm{m}^{-2} \text { ) }\end{array}$ \\
& $\begin{array}{c}\text { Abun- } \\
\text { dance } \\
\text { time }\end{array}$ & $\begin{array}{c}\text { Time } \\
\text { 4 weeks }\end{array}$ & \\
\hline Pseudopolydora & & & \\
paucibranchiata & 8 & $20.2 \pm 7.62$ & 0 \\
& 8 & $5.6 \pm 5.45$ & 160 \\
Pseudopolydora & 8 & $4.6 \pm 6.06$ & 320 \\
kempi & & & \\
& 0 & $2.8 \pm 2.39$ & 0 \\
& 0 & $0.4 \pm 0.68$ & 160 \\
& 0 & $0.6 \pm 1.67$ & 320 \\
\hline
\end{tabular}

\section{The Spionid Predator Escape Response}

Because spionids expose various parts while feeding (a function of OMA abundance) their ability to escape predatory attacks was investigated. In the laboratory, fish attacked only those spionids (Pseudopolydora paucibranchiata) which exposed their palps during feeding. The spionids withdrew rapidly into their tubes when touched suddenly by attacking fish and when swimming fish created water currents nearby. The flatfish Parophrys vetulus made 21 attacks on the spionids during the $2 \mathrm{~h}$ observation, all of which were unsuccessful. $P$. vetulus attacked by aiming for the palp junction at the top of the worm's tube. Attacked spionids remained within their tubes for 2-30 min before resuming feeding. The sculpin Leptocottus armatus did not attack the spionids. The flatfish have narrow 'picker' mouths, while the mouth of the sculpin is broad. Both species of fish occur at the study sites.

\section{DISCUSSION}

The data on Axiothella rubrocincta-spionid interactions suggest that the observed spatial segregation at the higher intertidal study sites was biologically induced. The occurrence of this pattern 'along' rather than 'across' the intertidal zone (spionids more abundant to the left and right of two A. rubrocincta patches) is, in itself, suggestive of a biological cause, for physical variation is expected to be minimal within a tidal zone.

Laboratory and field results (PAS stain analysis) clearly demonstrate that sediment reworking by Axiothella rubrocincta depletes $\mathrm{OMA}_{1}$ in the surficial sediment (Figs 4 and 5). Upper intertidal A. rubrocincta patches contain little $\mathrm{OMA}_{1}$ and are primarily composed of quartz mineral particles. Because field samples of OMA were collected only once, no estimate of its temporal variability can be made.

Dry sieving analysis (Fig. 6) corroborates the results of the PAS stain analysis in that the Axiothella rubrocincta patch sediment primarily consists of 'sand'sized mineral particles. Furthermore, among patches the lower intertidal patch (\#1) had significantly greater $\%$ silt-clay and $\% \mathrm{OMA}_{1}$ (Table 7). In other studies as well (Gallucci and Hylleberg, 1977; Johnson, 1977) these variables, in addition to \% organic carbon, were found to be positively related. Taghon et al. (1978) and studies cited therein suggest that OMA and the actual food of deposit feeders (bacteria) are positively related. Patch \# 1 had the highest resource (OMA) density among patches (Table 7, Fig. 5) which may account for it also having highest densities of spionids and feeding $A$. rubrocincta (Fig. 3, Table 1,5).

By experimentally studying Axiothella rubrocincta feeding behavior, the mechanisms by which it modifies substrates were determined. $A$. rubrocincta depletes OMA density within substrates by direct ingestion and by constantly reworking the substrate 
surface. Reworking may cause a physical breakdown and the removal of the aggregates from the area by currents. I observed (a) the selective feeding of surface OMA when individuals extended their bodies out of their sand tubes, and (b) the relocation of the feeding apertures to new locations. Episurface deposit-feeding (also described by Kudenov, 1971) is unique for $A$. rubrocincta because it lacks the palps or tentacles characteristic of most deposit-feeding species. Episurface feeding enhances the food-gathering ability because it is coordinated to select OMA. However, this behavior increases the probability of injury or death by vertebrate and invertebrate predators. A. rubrocincta is a prey item to common, visually feeding shorebirds such as the short-billed Black-bellied Plover Pluvialis squaterola and Dunlin Calidris alpina, and the longbilled, Marbled Godwit Limosa fedoa (Page and Stenzel, 1975). Individual $A$. rubrocincta that relocate their feeding apertures during periods of low OMA abundance expend energy in tube-building. This behavior took place regularly in the simulated sandflat and increased in frequency following experimental reduction of OMA. These data on $A$. rubrocincta feeding habits do not demonstrate that OMA is limiting in nature, but they clearly show that during periods of moderate to low OMA abundance feeding individuals incur risks and energy expenditures to obtain it. The data collectively suggest that OMA is an important food source to A. rubrocincta.

The results of laboratory and field data demonstrate that spionids are very dependent upon OMA for tubebuilding material and food. The OMA utilization of Pseudopolydora paucibranchiata was studied in detail. Laboratory experiments indicate that this spionid can construct tubes six times faster in sediment from Axiothella rubrocincta patches to which OMA are added. This increased efficiency is probably due to the use of light OMA which are easier to manipulate than mineral grains. Gut contents of $P$. paucibranchiata contained only OMA, and OMA feeding selectivity was observed in a variety of laboratory treatments. Furthermore, $P$. paucibranchiata radically changed its feeding behavior when OMA was not abundant. The modified behavior included hyperextension of the palps away from the tube aperture in order to increase the foraging area. In other studies, food availability has been hypothesized to control the foraging radii of ant (Bernstein, 1975) and deep-sea benthic (Jumars and Fauchald, 1977) species. In the latter study, food availability at given water depths has been hypothesized to ultimately determine the relative fitnesses of sessile vs. motile foragers. However, fitness in nature is a function of predation defense as well as feeding efficiency amongst potential competitors (Goss-Custard, 1977; Kerfoot, 1977; Vance, 1978). A recent northern California study (Toole, 1978) has reported an abundance of spionids in the guts of juvenile Parophrys vetulus. Other spionid predators include common shorebirds such as Limosa fedoa, Calidris alpina, and Limnodromus griseus (Page and Stenzel, 1975). Laboratory results in my study indicate that when OMA is abundant spionids extend only their palps in feeding, and can withdraw them without injury during a flatfish attack. However, when OMA is scarce, spionids modify their feeding behavior, reducing the effective predation defense of minimizing body exposure.

In the absence of potential bird and fish predators, the survival of adult (Pseudopolydora paucibranchiata) and larval ( $P$. kempi and $P$. paucibranchiata) spionids was very low in substrates containing high Axiothella rubrocincta densities. Survival was high in substrates devoid of $A$. rubrocincta (Table 10). Many of the adult spionids sympatric with $A$. rubrocincta died within their tubes, as indicated by the decomposing tubes. Spionid larvae were unsuccessful in colonizing substrates containing $A$. rubrocincta, possibly because they found these areas unsuitable and delayed settlement or they settled and subsequently died. Potential sources of larval spionid mortality caused by A. rubrocincta include OMA depletion, surface instability of the substrate and predation. Regardless of how the spionid larvae behaved, this experimental result emphasizes the importance of successful larval settlement in determining the adult distribution. This is in agreement with the adult-larval interactions hypothesis which states that 'the maintenance of these discrete dense assemblages in infaunal systems is due to interactions among the established infaunal individuals and settling larvae' (Woodin, 1976). This hypothesis and the current experimental result, while pinpointing the life-stage at which adult dispersion patterns may be formed, do not identify or describe the selective forces which structure infaunal communities.

This study's results collectively indicate that interspecific competition for OMA may be an important selective force determining the adult spionid distribution pattern around the upper-intertidal Axiothella rubrocincta Patches \#2 and \#3. Deposit-feeding A. rubrocincta deplete OMA (Table 7; Figs 4 and 5) which spionids 'preferentially' utilize for food (Table 8) and tube material (Table 9). At Patch \#1 (low intertidal) the high $A$. rubrocincta, spionid and OMA densities (Tables 1, 5 and 7) coupled with the lack of spionid segregation (Fig. 3) indicate that resource limitation (competition) is not a controlling factor in the adult spionid distribution. While these field and laboratory results are indicative of competitive interaction, they remain inconclusive as I have not demonstrated that OMA are ever limiting in nature. 
The instantaneous density of a resource (measured in this study) may not be well correlated with resource availability. No data are yet available on the flux of OMA as a polychaete resource in natural marine systems (for a discussion of the importance of resource renewal to deposit feeders consult Fenchel and Kofoed, 1976; Levinton and Lopez, 1977; and Lopez et al., 1977).

The intensity of a competitive interaction may be lessened by alternative outcomes such as segregation by habitat, food-type and feeding time (Schoener, 1974a). Levinton $(1972,1977)$ has hypothesized and provided evidence that interspecific competition for food between deposit feeders commonly occurs in temperate soft-substrate communities. The experimental results show that both Axiothella rubrocincta and the spionid guild utilize surface organic-mineral aggregates (OMA) ('relative specialists'), while $A$. rubrocincta also feeds nonselectively on a wide range of sediment sizes ('relative generalist') (see Kudenov, 1971 , for a complete discussion of A. rubrocincta feeding biology). The 'included niche' phenomenon can theoretically exist if the included species has a sufficiently high feeding efficiency (Schoener, 1974b). However, most spionids do not coexist with $A$. rubrocincta in the upper-intertidal zone on Lawson's Flat. 'Specialist' strategies are theoretically successful only when the resource availability is predictable and sufficiently high (Levins, 1968). The data indicate that the OMA density, and perhaps availability, for spionids within A. rubrocincta Patches \#2 and \# 3 does not meet these requirements. Spionids and $A$. rubrocincta have high diet overlap but low habitat overlap, a condition found for competing species of birds, lizards, fish, and crustaceans (Schoener, 1974a).

The general concept that substrate modification by deposit feeders may have a significant effect on the biological community is not new (Sanders, 1960; Sanders et al, 1962; Johnson, 1964; Fager, 1964; Gordon, 1966; Rhoads and Young, 1970; Myers, 1977a, b). In this study, distribution, feeding, tube-building, larval recruitment and adult survival of spionid polychaetes were found to be significantly affected by the substrate modifications of Axiothella rubrocincta. In a study of the effects of deposit feeders on suspension feeders, Rhoads and Young (1970) found that, unlike stations dominated by deposit-feeding bivalves, stations dominated by tubiculous deposit-feeding polychaetes were sandy in texture and of low organic content. The possibility that the Atlantic coast polychaetes had modified the substrate in a manner similar to A. rubrocincta in California was not reported. In further reviewing the literature, 'geographical replacements' (sensu Cody, 1974) of both Pacific coast families occur on the Atlantic coast. The sediment resource utilizations of most
Atlantic coast maldanids and spionids reported in the literature, are also associated with sandy and muddy sediments, respectively (Dorsett, 1961; McIntyre, 1961; Sanders et al., 1962; Galtsoff, 1964; Mangum, 1964; Blake, 1969, 1971, 1975; Whitlatch, 1976, 1977). The possibility that maldanid spionid competition occurs on the Atlantic coast has, to my knowledge, not been investigated.

In summary, interspecific competition between Axiothella rubrocincta and the spionid guild for a limited supply of OMA was implicated as a primary interaction accounting for the observed pattern of adult spionid spatial segregation. The segregation pattern is probably primarily established at the spionid larval settling stage, when adult $A$. rubrocincta prevent successful larval colonization. This segregation only occurred at the upper-intertidal $A$. rubrocincta patches, which contained the lowest densities of the OMA resource. In the lower intertidal zone where OMA was very abundant, the spionid density and distribution was probably determined by factors other than competition with $A$. rubrocincta.

Acknowledgements. I thank Sandy Benson, Dr. James Blake, Jay Carroll, Casey, Dr. Steven Obrebski, Dr. Russ Schmitt, Dr. Edmund Smith, Vicke Starczak, and Dr. Robert Whitlatch for generous assistance in the research and preparation of this manuscript. I am also grateful to Drs R. T. Paine and S. A. Woodin for reading and commenting on the manuscript.

\section{LITERATURE CITED}

Bernstein, R. (1975). Foraging strategies of ants in response to variable food density. Ecology, 56, 213-219.

Blake, J. (1969). Reproduction and larval development of Polydora from Northern New England (Polychaeta: Spionidae). Ophelia, 7, 1-63.

Blake, J. (1971). Revision of the Genus Polydora from the east coast of North America (Polychaeta: Spionidae). Smithson. Contr. Ecol., 75, 1-31

Blake, J. (1975). Phylum Annelida: Class Polychaeta. In: Light's Manual: Intertidal Invertebrates of the Central California Coast. University California Press, Berkeley. pp. 1-716.

Blake, J. and Woodwick, K. (1975). Reproduction and larval development of Pseudopolydora paucibranchiata (Okuda) and Pseudopolydora kempi (Southern) (Polychaeta: Spionidae). Biol. Bull. mar. biol. Lab., Woods Hole, 148 , 109-127

Cody, M. L. (1974). Competition and the Structure of Bird Communities, Princeton University Press, Princeton. (Monogr. Popul. Biol., 7, 1-318.)

Connell, J. H. (1961). The effects of competition, predation by Thais lapillus, and other factors on natural populations of the barnacle, Balanus balanoides. Ecol. Monogr., 31, 61-104.

Dayton, P. K. (1971). Competition, disturbance, and community organization: the provision and subsequent utilization of space in a rocky intertidal community. Ecol. Monogr., 41, 351-389. 
Deatwyler, C. C. (1966). Marine geology of Tomales Bay, central California. Pacific Marine Station, Res. Rept, 6, $1-169$.

Dorsett, D. A. (1961). The behavior of Polydora ciliata (Johnst.). Tube-building and burrowing. J. mar. biol. Ass U. K., 41, 577-590

Fager, E. W. (1964). Marine sediments: Effects of a tubebuilding polychaete. Science, $N$. Y., 143, 356-358.

Fauchauld, K and Jumars, P. A. (In press). The diet of worms: Polychaete feeding guilds. Oceanogr. mar. Biol

Fenchel, T. and Kofoed, L. H. (1976). Evidence for exploitative interspecific competition in mud snails (Hydrobiidae). Oikos, 27, 367-376.

Fenchel, T., Kofoed, L. H. and Lappalainen, A. (1975). Particle size-selection of two deposit feeders: The amphipod Corophium volutator and the prosobranch Hydrobia ulvae. Mar. Biol, 30, 119-128.

Gallucci, V. F. and Hylleberg, J. (1977). A quantification of some aspects of the growth of the bottom-feeding bivalve Macoma nasuta. Veliger, 19, 59-67.

Galtsoff, P. S. (1964). The American oyster Crassostrea virginica Gmelin. Fish. Bull., US. 64, 1-480.

Gordon, D. C. Jr. (1966). The effects of the deposit feeding polychaete Pectinaria gouldii on the intertidal sediments of Barnstable Harbor. Limnol. Oceanogr., 11, 327-331.

Goss-Custard, J. D. (1977). Predator responses and prey mortality in redshank, Tringa totanus (1.), and a preferred prey, Corophium volutator (Pallus). J. Anim. Ecol., 46, 21-35.

Hargrave, B. T. (1972). Aerobic decomposition of sediment and detritus as a function of particle surface area and organic content. Limnol. Oceanogr., 17, 583-596.

Harper, J. L. (1969). The role of predation in vegetational diversity. In G. M. Woodwell and H. Smith (Eds), Diversity and Stability in Ecological Systems. Brookhaven National Laboratory, New York. pp. 48-62.

Howege, H. (1976). Distribution and abundance of soft-sediment intertidal polychaetes. M. S. thesis, University of Pacific, Dillon Beach, Calif.

Humason, G. L. (1967). Animal Tissue Techniques, 2nd ed., Freman, San Francisco.

Johnson, R. G. (1964). The community approach to paleoecology. In J. Imbrie and N. Newell (Eds), Approaches to Paleoecology. Wiley, New York. pp. 107-134.

Johnson, R. G. (1965). Temperature variation in the infaunal environment of a sandflat. Limnol. Oceanogr., 10 , $114-120$

Johnson, R. G. (1967a). Salinity of interstitial water in a sandy beach. Limnol. Oceanogr., 12, 1-7.

Johnson, R. G. (1967b). The vertical distribution of the infauna of a sandflat. Ecology, 45, 571-578.

Johnson, R. G. (1970). Variations in diversity within benthic marine communities. Am. Nat, 104, 285-300.

Johnson, R. G. (1971). Animal-sediment relations in shallow water benthic communities. Mar. Geol, 11, 93-104.

Johnson, R. G. (1974). Particulate matter at the sedimentwater interface in coastal environments. J. Mar. Res., 32, 313-330.

Johnson, R. G. (1977). Vertical variation in particulate matter in the upper twenty centimeters of marine sediments. $J$. Mar. Res., 35, 273-282.

Jumars, P. A. and Fauchauld, K. (1977). Between-community contrasts in successful polychaete feeding strategies. In B. C. Coull (Ed.), Ecology of Marine Benthos. University of South Carolina Press, Columbia. pp. 191-227.

Keppel, G. (1973). Design and Analysis, A Researcher's Handbook, Prentice-Hall Inc., New Jersey.
Kerfoot, W. C. (1977). Competition in cladoceran communities: The cost of evolving defenses against copepod predation. Ecology, 58, 303-313

Kudenov, J. D. (1971). Sediment reworking rates and the feeding ecology of Axiothella rubrocincta (Polychaeta: Maldanidae). M. S. thesis, University of Pacific, Dillon Beach, Calif.

Levins, R. (1968). Evolution in Changing Environments: Some Theoretical Explorations, Princeton University Press, Princeton. (Monogr. Popul. Biol, 2, 1-120.)

Levinton, J. S. (1972). Stability and trophic structure in deposit-feeding and suspension-feeding communities. Am. Nat., 106, 472-486.

Levinton, J. S. (1977). Ecology of shallow water depositfeeding communities in Quisset Harbor, Massachusetts. In B. C. Coull (Ed.), Ecology of Marine Benthos. University of South Carolina Press, Columbia. pp. 191-227.

Levinton, J. S. and Lopez, G. R. (1977). A model of renewable resources and limitation of deposit-feeding benthic populations. Oecologia, 31, 191-199.

Lopez, G. R., Levinton, J. S. and Slobodkin, L. B. (1977). The effect of grazing by the detritivore Orchestia grillus on Spartina litter and its associated microbial community. Oecologia, 30, 111-127.

Mangum, C. P. (1964). Studies on speciation in maldanid polychaetes of North American Atlantic coast. II. Distribution and competitive interaction of five sympatric species. Limnol. Oceanogr., 9, 12-26.

McIntyre, A. D. (1961). Meiobenthos of sub-littoral muds. $J$. mar. biol. Ass. U. K., 41, 599-616

Myers, A. C. (1977a). Sediment processing in a marine subtidal sandy bottom community: I. Physical aspects. J. Mar. Res., 35, 609-632.

Myers, A. C. (1977b). Sediment processing in a marine subtidal sandy bottom community: II. Biological consequences. J. Mar. Res., 35, 633-647.

Page, G. and Stenzel, L. (1975). Aspects of the ecology of shorebirds on Bolinas Lagoon. Dept. of Parks and Rec. Marin Co., Calif., 1-89. (Unpubl. rept.)

Paine, R. T. (1966). Food web complexity and species diversity. Am. Nat., 100, 65-75.

Pianka, E. R. (1973). The structure of lizard communities. A. Rev. Ecol. \& Syst., 4, 53-74.

Reise, K. \{1978). Experiments on epibenthic predation in the Wadden Sea. Helgoländer wiss. Meeresunters., 31 , 55-101.

Rhoads, D. C. and Young, D. K. (1970). The influence of deposit-feeding organisms on sediment stability and community trophic structures. J. Mar. Res., 28, 150-170.

Ronan, T. E. Jr. (1975). Structural and paleoecological aspects of a modern soft-sediment community: An experimental field study. Ph. D. thesis, University of California, Davis.

Root, R. B. (1967). The niche exploitation pattern of the bluegray gnatcatcher. Ecol. Monogr., 37, 317-350.

Sanders, H. L. (1960). Benthic studies in Buzzards Bay. III. The structure of the soft-bottom community. Limnol. Oceanogr, 5, 138-153

Sanders, H. L., Goudsmit, E. M., Mills, E. L. and Hampson, G. E. (1962). A study of the intertidal fauna of Barnstable Harbor, Massachusetts. Limnol. Oceanogr., 7, 63-79.

Schoener, T. W. (1974a). Resource partitioning in ecological communities. Science, N. Y., 185, 27-39.

Schoener, T. W. (1974b). Competition and the form of habitat shift. Theor. Pop. Biol., 6, 265-307.

Sokal, R. R. and Rohlf, F. J. (1969). Biometry: The Principles and Practice of Statistics in Biological Research, Freeman, San Francisco. 
Taghon, G. L., Self, R. F. L. and Jumars, P. A. (1978). Predicting particle selection by deposit feeders: A model and its implications. Limnol. Oceanogr., 23, 752-759.

Toole, C. L. (1978). Intertidal feeding of juvenile English Sole (Parophrys vetulus) in Humboldt Bay, California. M. A. thesis, Humboldt State University, Arcata, Calif.

Vance, R. R. (1978). Predation and resource partitioning in one predator-two prey model communities. Am. Nat., 112, $797-813$

Weinberg, J. R. (1978). The synecology of dense assemblages of the deposit-feeding polychaete, Axiothella rubrocincta (Maldanidae). M. S. thesis, University of Pacific, Dillon Beach, California.

Whitlatch, R. B. (1976). Seasonality, species diversity, and patterns of resource utilization in a marine deposit-feeding community. $\mathrm{Ph}$. D. thesis, University of Chicago, Chicago, Ill.

Whitlatch, R. B. (1977). Seasonal changes in the community structure of the macrobenthos inhabiting the intertidal sand and mudflats of Barnstable Harbor, Massachusetts. Biol. Bull. mar. biol. Lab., Woods Hole, 152, 275-294.

Whitlatch, R. B. and Johnson, R. G. (1974). Methods for staining organic matter in marine sediments. $J$. Sed. Pet., 44, $1310-1312$

Woodin, S. A. (1974). Polychaete abundance patterns in a marine soft-sediment environment: the importance of biological interactions. Ecol. Monogr., 44, 171-187.

Woodin, S. A. (1976). Adult-larval interactions in dense infaunal assemblages: Patterns of abundance. J. Mar. Res., 34, 25-41.

Woodin, S. A. (1977). Algal 'gardening' behavior by neried polychaetes: Effects on soft-bottom community structure. Mar. Biol., 44, 39-42.

Zabawa, C. F. (1978). Microstructure of agglomerated suspended sediments in Northern Chesapeake Bay Estuary. Science, N. Y., 202, 49-51.

This paper was presented by Dr. H. von Westernhagen; it was accepted for printing on August 24, 1979. 